\title{
FDI Spillover from G20 Countries, Policy Support Degree and China's Regional Technology Development
}

\author{
XIAO LEI \\ School of Information Management, Beijing Information Science and Technology University \\ Beijing, 100192, China
}

\begin{abstract}
Based on the panel data from 2008 to 2017, this paper empirically studies the FDI spillover effect and Hansen threshold effect of G20 countries on China's regional technological progress. The results show that: 1. The FDI spillover from G20 countries has a significant effect on promoting regional technological progress, with developed countries contributing nearly three times as much as developing countries. 2. The policy support degree of host country shows a significant single threshold effect on FDI spillover. 3. The driving forces for regional technological upgrading include research and development capability, human capital, industrial structure and economic development level. Finally, suggestions are put forward according to the research conclusions.
\end{abstract}

Keywords-FDI spillover; Threshold effect; Technological progress; Policy support degree

\section{INTRODUCTION}

Under the condition of open economy, transnational capital on a global scale to find suitable investment opportunities for economic, technological, environmental and other factors of cross-regional development, so the flow of capital in the host configuration usually contain the R\&D input, purposeful activities, technical personnel flow brought by the factors such as technology of involuntary diffusion, which is called "spillover effect" of knowledge.

MacDougall (1960) first studied the spillover effect of FDI on host countries and confirmed the "economic externality" of FDI spillover to enterprises in host countries [1].With the development of endogenous economic growth theory and the expansion of knowledge production function, scholars began to study and explore the impact of FDI on innovation and technology of host countries. Kokko (2000) found that FDI of transnational corporations had a significant promoting effect on the technological and productivity progress of host countries [2]. Javorcik(2003) studied the industrial panel data of Lithuania and found that the backward correlation between industries was positively correlated with the total factor productivity, but the forward correlation was not significant[3]. In China, Chen(2008) established a model framework based on domestic knowledge capital, FDI and technological progress. Empirical studies have found that R\&D capital spillover of FDI channels promotes domestic technological progress[4]. $\mathrm{He}(2007)$ used DEA to decompose total factor productivity, and demonstrated the impact of human capital, international import and export and FDI on total factor productivity[5].

Similar differences of empirical results lead to further thinking on the constraints of FDI spillover: Borensztein(1998) proposed that FDI spillover effects were affected by the human capital of host country, and designed the endogenous growth model containing the FDI spillover of human capital[6].Wang(1992)considered that technology gap affected FDI spillover effect, and the greater the technology gap, the greater the spillover effect FDI[7]. According to the empirical analysis of China, Huang (2007) firstly used the non-linear cross term of FDI and technology level, and found that the technology spillover of FDI has the threshold effect of technology level absorption, and when the technology level of host country exceeds the threshold value, the spillover effect weakens[8]. After that, a large number of scholars have confirmed the multi-factor constraint relations of FDI spillover [9-12].

\section{RESEARCH BACKGROUND}

The G20 group has made great achievements in international coordination and cooperation, economic system reform and capital integration. China's FDI reached $\$ 144$ billion in 2017, making it the world's second largest inflow of foreign investment, with the G20 accounting for more than 70 percent of China's total FDI. As we all know the G20 group has been paid much attention to its economic effect, but is there any technological spillover effect for G20 countries to China? New technological revolution puts more emphasis on the internationalization and diversification of $R \& D$, so the government's emphasis on $\mathrm{R} \& \mathrm{D}$, especially the degree of participation, is particularly important for the development of domestic technology. Is there any correlation between FDI spillover effect and government R\&D activities? In recent years, with the rapid development of China's economy and the continuous optimization and upgrading of industrial institutions, are these elements related to technological upgrading? Based on the above questions, this paper will carry out an empirical analysis on the FDI spillover effect of G20 countries and China's technological progress.

National Science Foundation of China (NO. 70973011) and Science and

Technology Projects of Beijing Municipal Education

Commission(NO.SM201811232003) 


\section{MODEL CONSTRUCTION AND INDEX SELECTION}

The explained variable is regional technology level, measured by total factor productivity. Based on the CobbDouglas production function combined with the existing literature, the explanatory variables of the model were selected for FDI spillovers in G20 countries, as well as the regional R\&D level, human capital, economic level and industrial structure. In order to eliminate the model heteroscedasticity as far as possible, the model variable was taken in logarithmic form. FDI spillovers and regional R\&D level variables take the lag phase value and establish model $\mathrm{A}$ as below:

$$
\begin{aligned}
\ln T_{i, t}= & \alpha_{0}+\beta_{1} \ln S_{i, t-1}^{f d i}+\beta_{2} \ln R_{i, t-1}+\beta_{3} \ln H_{i, t} \\
& +\beta_{4} \ln G_{i, t}+\beta_{5} \ln I_{i, t}+\xi_{i, t}+u_{i, t}
\end{aligned}
$$

$i$ is the province, $t$ is year, $T$ is regional technology level, $S^{f d i}$ is FDI spillover, $R$ is regional R\&D capacity, $H$ is regional human capital, $G$ is regional economic level, $I$ is regional industrial structure; $\alpha_{0}$ is the intercept term, $\beta$ is the elastic coefficient, $\xi$ represents the fixed section effect, $u$ represents the random disturbance term. At the same time, the paper introduced 'policy support degree' as the threshold variable of FDI spillover, and explored whether the government's R\&D support degree would affect the FDI spillover effect. Threshold model $\mathrm{B}$ is established as below, $\delta$ is the threshold variable, $\gamma$ is the threshold value:

$$
\begin{aligned}
\ln T_{i, t}= & \alpha_{0}+\beta_{1}^{\prime} \ln S_{i, t-1}^{f d i}\left(\delta_{i, t} \leq \gamma_{1}\right)+\beta_{1}^{\prime \prime} \ln S_{i, t-1}^{f d i}\left(\delta_{i, t}>\gamma_{1}\right) \\
& +\beta_{2} \ln R_{i, t-1}+\beta_{3} \ln H_{i, t}+\beta_{4} \ln G_{i, t} \\
& +\beta_{5} \ln I_{i, t}+\xi_{i, t}+u_{i, t}
\end{aligned}
$$

Articles intercepted $2008 \sim 2017$ year to be observed, selected China's 30 provinces except Tibet, Hong Kong, Macao and Taiwan. Due to the problem of model estimation bias, the sample countries of the G20 group do not include the EU.

The Malmquist index based on DEA method was used to measure the regional TFP. The base period was selected in 2008 , measured by the regional output, labor force variables and capital stock. Due to data loss, FDI spillovers were calculated using the following model:

$$
S_{i, t}^{f d i}=\sum\left(F D I_{i, t} / F D I_{t}\right)\left(F D I_{j, t} / K_{j, t}\right) S_{j, t}^{d}
$$

$j$ is the sample country, $F D I_{i, t}$ is FDI of $i, F D I_{t}$ is China's total FDI, $F D I_{j, t}$ is FDI from $j, K_{j, t}$ is the total amount of fixed asset formation of $j, S_{j, t}^{d}$ is R\&D stock, calculated by the perpetual inventory method, and the depreciation rate is $15 \%$.

Regional R\&D capacity adopts the perpetual inventory method of $R \& D$ investment to calculate, and the depreciation rate is $15 \%$. Human capital is calculated by education years per capita. Economic level is measured by GDP per capita. As for the measurement of industrial structure, this paper uses the ratio between the proportion of output value of secondary industry and that of tertiary industry. Policy support degree is measured by the proportion of government R\&D input in GDP, represents the degree of support for $\mathrm{R} \& \mathrm{D}$ innovation activities in different regions.

The data sources mainly include: China statistical yearbook (employment number, GDP per capita, education level of employment personnel, FDI values, the secondary and tertiary industry data); China science and technology statistical yearbook (regional R\&D data, international $R \& D$ related data); World bank web site and OECD database (fixed asset formation and R\&D input of sample countries). All monetary measurements are converted to 2008 constant prices in millions of dollars.

\section{STATIONARY TEST}

Results of LLC test, Breitung test, IPS test, Fisher ADF, Fisher PP test showed that the variable passed the usual significance test $(1 \%$ or $5 \%)$, proving that the panel data sequence was stable. The Pedroni test was then performed as below:

TABLE I CO-INTEGRATION RELATIONSHIP TEST RESULTS

\begin{tabular}{cccc}
\hline Pedroni test & Panel V & Panel Rho & Panel PP \\
& $-8.457 .280(0.000)$ & $-9.012(0.000)$ & $-7.234(0.000)$ \\
\hline Kroup Rho & Group PP & Panel ADF \\
& $-6.173(0.000)$ & $-11.198(0.000)$ & $-7.701(0.000)$ \\
\hline Kao test & ADF & & \\
& $-19.474(0.000)$ & & \\
\hline
\end{tabular}

$\mathrm{P}$ value is shown in parentheses.

Panel ADF and other tests all reject the null hypothesis of 'no co-integration relationship' at the significance level of $1 \%$, indicating the existence of co-integration relationship between variables, which can be used for Panel data regression analysis.

\section{EMPIRICAL RESULTS}

Model A was estimated by using the Stata12.0 tool for all samples, developed countries and developing countries. Based on the panel threshold model put forward by Hansen[13-14], the threshold of Model B is tested and regression, and the number of self-sampling is 500.The results are summarized in Table II and Table III as bellows:

TABLE II THRESHOLD TEST RESULTS

\begin{tabular}{lccc}
\hline & & FDI Spillover & P Value \\
\hline Single & threshold & 0.357 & 0.000 \\
value & & & \\
Double & threshold & 0.211 & 0.246 \\
value & & 0.345 & \\
\hline
\end{tabular}

Policy support degree of host country and region has a significant single threshold effect on FDI spillover, and the threshold value is 0.357 . The double threshold effect did not pass the significance test. 
TABLE III

PLS AND HANSEN REGRESSION RESULT

\begin{tabular}{|c|c|c|c|c|}
\hline Variable & All samples & $\begin{array}{c}\text { Model A } \\
\text { G20 developed } \\
\text { countries }\end{array}$ & $\begin{array}{l}\text { G20 developing } \\
\text { countries }\end{array}$ & Model B \\
\hline $\ln S_{i, t-1}^{f d i}$ & $\begin{array}{c}0.134 * * * \\
(8.81)\end{array}$ & $\begin{array}{l}0.212^{* * *} \\
(7.48)\end{array}$ & $\begin{array}{c}0.075^{* *} \\
(1.89)\end{array}$ & - \\
\hline $\ln S_{i, t-1}^{f d i}\left(\delta_{i, t} \leq \gamma_{1}\right)$ & - & - & - & $\begin{array}{c}0.077 * * * \\
(5.63)\end{array}$ \\
\hline $\ln S_{i, t-1}^{f d i}\left(\delta_{i, t}>\gamma_{1}\right)$ & - & - & - & $\begin{array}{l}0.176^{* * * *} \\
(7.73)\end{array}$ \\
\hline $\ln R_{i, t-1}$ & $\begin{array}{c}0.336 * * * \\
(11.56)\end{array}$ & $\begin{array}{c}0.290 * * * \\
(9.71)\end{array}$ & $\begin{array}{c}0.323 * * * \\
(6.11)\end{array}$ & $\begin{array}{c}0.312 * * * \\
(7.56)\end{array}$ \\
\hline $\ln H_{i, t}$ & $\begin{array}{c}0.158^{* * *} \\
(14.01)\end{array}$ & $\begin{array}{c}0.174 * * * \\
(10.23)\end{array}$ & $\begin{array}{c}0.150^{* *} \\
(2.58)\end{array}$ & $\begin{array}{l}0.187 * * * \\
(5.98)\end{array}$ \\
\hline $\ln G_{i, t}$ & $\begin{array}{c}0.085^{* * *} \\
(8.02)\end{array}$ & $\begin{array}{c}0.116 * * * \\
(10.89)\end{array}$ & $\begin{array}{c}0.079 * * * \\
(6.49)\end{array}$ & $\begin{array}{l}0.081 * * * \\
(7.03)\end{array}$ \\
\hline $\ln I_{i, t}$ & $\begin{array}{l}0.121 * * \\
(2.46)\end{array}$ & $\begin{array}{c}0.174 * * * \\
(4.77)\end{array}$ & $\begin{array}{l}0.214 \\
(1.18)\end{array}$ & $\begin{array}{c}0.144 * * \\
(2.64)\end{array}$ \\
\hline$R^{2}$ & 0.672 & 0.655 & 0.721 & 0.689 \\
\hline
\end{tabular}

\section{CONCLUSION}

For all samples, FDI spillover from G20 countries significantly promoted the improvement of regional technical level, and the contribute rate is 0.134 (significance at $1 \%$ level).Regional R\&D capability, human capital, industrial structure and economic level are also the main drivers for regional technology improvement, with contribution rates of $0.336,0.158,0.121$ and 0.085 respectively, which are significant at least at the level of $5 \%$.

The empirical results confirmed that R\&D capability and human capital is an important driving force of China's regional technology and innovation like majority literatures, and this study firstly found that the variable of the industrial structure acts an obvious role in promoting Chinese technology, which confirmed the necessity of the transformation and upgrading of industry under the strategy of science and technology and rejuvenating the country. Now it is generally recognized that the increase of the proportion of tertiary industry is an important symbol to measure the economic development, social and technological progress of countries and regions.

G20 developed countries' FDI spillover effect is more pronounced on regional technology promotion, with the contribution rate of 0.212 (significance at $1 \%$ level), nearly three times of the G20 developing countries. It is indicated that the regions mainly absorb the spillover effect of developed countries, and the foreign capital of developing countries in the sample has a weak effect on the improvement of regional technology in China due to the late start and less investment in technological purposes.

When the policy support degree below the threshold value 0.357 , the contribution rate of FDI spillover to the regional technical level is only 0.077, and the proportion of the observation value of government support below the threshold value is as high as $67.61 \%$ in the sample, which proves that insufficient government support significantly restricts FDI spillover absorption. When above the threshold value, the contribution rate of FDI spillover to the regional technology level in G20 countries is 0.176, indicating that the high government investment in research and development activities has strengthened the region's ability to absorb foreign capital spillover.

According to the research result, there are some suggestions for the Chinese government and enterprises:

(1) Continue to encourage and guide foreign investment in developed G20 countries, strengthen trade and investment cooperation with developing G20 countries, and create a favorable investment environment.

(2) Speed up the optimization of industrial structure, build a modern industrial system dominated by tertiary industry, and actively promote the added value of science and technology in the primary, secondary and tertiary industries;

(3) The government should pay more attention to R\&D activities, give full play to the government's role of guidance and supervision in $\mathrm{R} \& \mathrm{D}$ process, so as to enhance the region's ability to absorb FDI spillover effects.

\section{ACKNOWLEDGMENT}

This research was financially supported by the National Science Foundation of China (NO. 70973011) and Science and Technology Projects of Beijing Municipal Education Commission(NO.SM201811232003). The authors also gratefully acknowledge the helpful comments and suggestions of the reviewers, which have improved the presentation. 


\section{REFERENCES}

[1] MacDougall G. The Benefits and Costs of Private Investment from Abroad: A Theoretical Approach[J]. Economic Record,1960(36): 13-35.

[2] Kokko A . Technology, market characteristics, and spillovers[J]. Journal of Development Economics, 2000, 43(2):279-293.

[3] Javorcik, B.S., Spatareanu, M. To Share or Not to Share: Does Local Participation Matter for Spillover from Foreign Direct Investment?[R]. Policy Research Working Paper Series 3118, The World Bank, 2003.

[4] Chen J, Liu W, Zhang Y, et al. An empirical study on FDI international knowledge spillovers and regional economic development in China[J]. Frontiers of Economics in China, 2010, 5(3):489-508.

[5] He Q. Openness and TFP Growth: An Empirical Study Based on the Inter-provincial Panel Data in China[J]. China Economic Quarterly, 2007, 6(4):1127-1142.

[6] E. Borensztein, J. De Gregorio, J-W. Lee. How does foreign direct investment affect economic growth? 1[J]. Journal of International Economics, 1995, 45(1):115-135.

[7] Wang, Blomstrom M. Foreign Investment and Technology Transfer: A Simple Mode[J]. European Economic Review, 1992(36): 34-41.

[8] Huang L, Fan Y, Liu X. Technology Spillovers of FDI Based on Host's Absorptive Capacity: An Empirical Analysis[J]. China Soft Science, 2007(3):30-34.

[9] LI Y, Han B. Double-edged effects of the technology gap and technology spillovers of FDI:an empirical analysis[J]. Studies in Science of Science, 2011,29(2): 220-229.

[10] Wang J . The Spillover Effect of Service FDI on Host Countries' TFP: An Analysis Based on the Panel Data of OECD Countries[J]. International Economics \& Trade Research,2014, 30(9):33-48.

[11] Wang H, Liu H, Cao Z, et al. FDI technology spillover and threshold effect of the technology gap: regional differences in the Chinese industrial sector[J]. Springerplus, 2016, 5(1):323.

[12] Zhang L. The knowledge spillover effects of FDI on the productivity and efficiency of research activities in China[J]. China Economic Review, 2017(42):1-14.

[13] Hansen B E. Threshold effects in non-dynamic panels: Estimation, testing, and inference[J]. Journal of econometrics, 1999, 93(2): 345-368.

[14] Hansen B E. Sample splitting and threshold estimation [J]. Econometrica, 2000, 68(3): 575-603. 